\title{
Työssäoppiminen ammattillisen koulutuksen merkittävin koskaan toteutettu uudistus?
}

\author{
Mari Räkköläinen ja \\ Ilkka Uusitalo (toim): \\ Työssäoppiminen ja \\ ohjaus ammatillisissa \\ oppilaitoksissa. Kus- \\ tannusosakeyhtiö Tam- \\ mi. Tampere 2001. ISBN \\ 951-26-4660-9.
}

Mari Räkköläisen ja Ilkka Uusitalon toimittamassa kirjassa "Työssäoppiminen ja ohjaus ammatillisissa oppilaitoksissa" käsitellään työssä oppimista ammatillisiin tutkintoihin kuuluvien työssäoppimisjaksojen näkökulmasta. Tässä yhteydessä työssäoppiminen myös kirjoitetaan yhteen. 195 sivulla on annettu tilaa neljälle kokonaisuudelle: ammattiin oppimisen muutos, oppilaitoksen ja työelämän yhteistyö, välineitä työssäoppimisen ohjaamiseen ja arviointi. Kirja koostuu artikkeleista ja kuhunkin neljään kokonaisuuteen liittyvistä teemasivuista, jotka sisältävät jaksoon liittyviä harjoituksia ja pohdintatehtäviä.

\section{Ilkka Uusitalo tarkastelee ammatillisen koulutuksen muutosta painottaen vuoro- vaikutusta. Perinteinen, epä- yhtenäisesti ja vailla suuria oppimistavoitteita toteutettu työharjoittelu korvautuu vä- hintään 20 opintoviikon työssäoppimisella ja opinnol- listaa jakson, jonka kautta opiskelija on aiemmin ilman suunnitelmaa vain tutustunut alansa ammattityöhön ja luo- nut kontakteja työelämään. Uudenlaisen työssä oppimi-}

sen tarpeen selittäjänä käytetään sekä työelämän nopeaa teknologista kehitystä että jälkiteollisen yhteiskunnan ammattitaitovaatimusten jatkuvaa muutosta, mikä vaikuttaa myös tarpeeseen tiivistää vuorovaikutusta työn ja koulutuksen välillä. Uusitalo myös määrittelee tässä yhteydessä koko kirjassa käytettävän työssäoppimisen käsitteen: "Työssäoppimisella tarkoitetaan tässä kirjassa ensisijaisesti opiskelijan omaan osaamiseen, kokemukseen ja työpaikkaohjaajan ja oppilaitoksen opettajan ohjaukseen perustuvaa työympäristössä ja työyhteisössä tapahtuvaa oppimista."

\section{Oppilaitoksen ja työ-} elämän yhteistyötä käsittelevässä jaksossa Mari Räkköläinen tuo esille ajatuksia näkökulmasta, jossa painottuu työelämäläheisyys yhä keskeisempänä oppilaitosstrategiana. Oppilaitosten olisi luotava toiminnastaan palvelujärjestelmä, jonka vaikuttavuus ulottuisi yhä selkeämmin ja ajanmukaisemmin sekä työllistymistä että tutkintojen suorittamista palvelevaksi toiminnaksi. Työssäoppiminen on yksi väline oppilaitoksen uuden strategian muotoilussa. Se edellyttää ennen kaikkea pedagogisten ratkaisujen löytämistä tuon lähentämisen toteuttamiseksi. Se edellyttää myös oppimisen suuntaa koskevien arviointikriteerien nostamista esille, sillä oppiminen on se ydinprosessi, josta yhteistyön on lähdettävä. Räkköläinen viittaa siihen, kuinka oppimisen ohjaami- nen nousee keskeisimmäksi välineeksi työssäoppimisen ja kouluoppimisen integroimiseksi.

\section{Helena Santala käsittelee} työssäoppimisyhteistyötä eri toimijoiden näkökulmista hyvin yleisellä roolien ja mahdollisten sisältöjen tasolla. Artikkeli perustuu pitkälti omiin kokemuksiin, havaintoihin, kursivoituihin lainauksiin (mahdollisesti arviointipalautteisiin) ja opetushallituksen työssäoppimisen opetussuunnitelman perusteiden lainauksiin (www.edu.fi/tonet). Seija Sjöholmin tarkastelu nousee työnantajan näkökulmasta ja reaalisen kehittämishankkeen toteutuksesta. Ypäjän vanhus- ja vammaistyön koulutus- ja kehittämishankkeessa opiskelijat ovat osallistuneet ekspansiivisen oppimisen mallin mukaan toteutettuun kehittävään kokeiluun, jossa myös työyhteisö on itse tavoitellut uusien toimintamallien ja -järjestelmän kehittämistä. Opiskelijoille on tarjoutunut työssäoppimisen kautta mahdollisuus osallistua aitoon toimintajärjestelmää muuttavaan prosessiin aktiivisena subjektina. Tämä on tarjonnut luonnollisen alustan yhteiseen työkäytännön kehittämiseen ja samalla myös siinä käytettävien menetelmien oppimiseen. Sini-Vuokko Kvick ja Pia Pennala esittelevät kokeilemaansa tiimityöskentelyä, jolla on pyritty tukemaan ja ohjaamaan työssäoppimisjakson aikana opiskelijoiden kokemusten reflektointia. Itse tiimin toimintaan 
on kohdistettu keskeinen huomio ja pyritty siitä saamaan aikaan työssäoppimisen reflektoinnille suotuisa foorumi.

\section{Ohjaus on kirjan toinen}

keskeinen teema, mikä myös sivumääräisesti saa eri kokonaisuuksista eniten tilaa. Ilkka Uusitalon toisessa artikkelissa ohjauksen teemaan johdatellaan sosialisaatioteoreettisen näkökulman kautta. Työssäoppimisen sosiaalistumisprosessin voi Uusitalon mukaan ajatella muodostuvan seuraavista vaiheista: 1 . mielikuvatyöskentely ennen työyhteisöön siirtymistä, 2. tiedonhankintavaihe organisaatiosta ja ihmisistä, 3. sosiaalisten suhteiden luomisen vaihe ja 4 . oman työroolin muotoilun vaihe. Ennen kaikkea artikkeli nostaa esille sen, että työssäoppiminen on rationaalisen ja teknisen työskentelyn ohella opiskelijalle myös yhteisöön ja sen sosiaalisiin käytäntöihin, suhteisiin ja arvoihin sosiaalistumisen prosessi, jossa oma rooli on eri vaiheiden myötä haettava ja työstettävä. Toteutetussa projektissa (josta nähtävästi myös kursivoidut lainaukset ovat) on käytetty ohjauksen välineenä mm. mielikuvatyöskentelyä "sosiaalistumista" alkuun panevana ja helpottavana välineenä. Sosialisaationäkökulmaa olisi toki voinut laajentaa vielä käsittelemään vaikkapa eri toimintajärjestelmien (tai opettajien) omaa sosialisaatiota työssäoppimiseen ja erityisesti sitä millaisia muutoksia työssäoppimisen voi odottaa aiheuttavan työpaikoilla.

Mari Räkköläisen (toisessa) artikkelissa työssäoppimisen ohjauksesta ohjaus määritel- lään aluksi vuorovaikutuksen menetelmäksi, dialogiksi ja opettajan näkökulmasta kokonaiseksi opetussuunnitelmatyön ja ohjaustilanteiden (kohtaamisten) järjestämisen ja prosessoinnin välineeksi. Asiaa tarkastellaan opettajan ja ohjaajan näkökulmasta, jolloin se myös yhdistetään selkeästi opetussuunnitelmatyöhön ja henkilökohtaisten oppimissuunnitelmien (hops) tekemisen välttämättömyyteen. Opsin, hopsin ja työssäoppimisen yhteensovittaminen ja nivoutuminen kokonaiseksi ja yhteiseksi oppimiskulttuuriksi on pitkälti sen varassa, kuinka hyvin näiden väliset suhteet saadaan toimimaan. Tässä nähtävästi on myös perustelu ohjauksen tarpeen kasvulle. Artikkelissa käsitellään laajasti ja melko yleisesti ohjaussuhteen ilmiöitä (paralleeli-ilmiö, mallinmurtaminen, raamittaminen), opiskelijaryhmän ohjaamista (ryhmän systeemit, ryhmän kehittymiseen liittyviä prosessit ja tilat) sekä ohjaussuhdetta ja siihen liittyviä oppimisen ongelmia, jotka yleisyydessään ja abstrakteina tässä yhteydessä antavat itse työssäoppimisen ohjauksen spesifille hahmottamiselle varsin vähän välineitä. Sen sijaan ohjauksen kulkua eli prosessia käsittelevä kappale on paikallaan mallitettaessa sitä, millaisia vaiheita ja elementtejä ohjaus voi ohjaussuunnitelmien, sopimisten, oppimistehtävien, reflektoinnin ja palautteen kautta saada ja millaisia interventioita ohjaaja voi tuolloin käyttää. Jos prosessi luokin mallin myös sille, että opettaja pystyy luomaan itselleen välttämättömän ohjausnäkemyksen, artikkelissa olisi voinut myös määritellä ohjauksen käsitteen selkeästi ope- tuksesta eroavaksi, jolloin myös se auttaisi opettajaa käsitteellisestikin löytämään identifioitumisen välineitä uuteen rooliinsa.

\section{Soili Keskinen tiivistää}

ohjauksen ytimekkäästi opiskelijan attribuoinnin eli oman toiminnan ja ympäristön selittämisen ja tulkitsemisen tukemiseksi, josta avautuu uusia mahdollisuuksia oppimisen ja merkitysperspektiivien käsittelylle. Ilkka Uusitalo käsittelee kolmannessa artikkelissaan oppimistehtäviä, jotka keskeisesti voivat toimia koulun ja työpaikan toimintajärjestelmiä yhdistävänä linkkinä ja samalla myös itse työssäoppimisen opinnollistajina. Projektityöskentely, jossa myös työyhteisö on aloitteellisesti sitoutunut kehittämishankkeeseen (edellä mainittu Ypäjän kokeilu), antaa opiskelijoille ja oppimistehtäville luontevan ja rajoja ylittävän foorumin. Ritva Mäntylän artikkelissa käsitellään oppimispäiväkirjaa oman toiminnan ajattelun (reflektion) välineenä. Samalla se toimii kokemusten ulkoistamisena ja tallentamisena myös ohjaustilanteita varten, joissa palataan käsittelemään oppijan oppimisprosessia ja ammatillista kasvua työssäoppimisen jaksojen aikana.

\section{Viimeisessä osiossa}

Seppo Helakorpi käsittelee osaamisen arviointia lähtien ammattisivistyksen ideasta. Se edellyttää myös itsestään tietoista työntekijää, joka pystyy ikään kuin nousemaan metatasolle ja arvioimaan oman toimintansa, osaamisensa ja persoonansa merkityksiä ja vastuuta jatkuvasti kehittyvän työn konteksteissa. Määrälli- 
sen, laadullisen, itsearvioinnin, ulkoisen arvioinnin, kolmikantaperiaatteen esittelyjen kautta Helakorpi tulee työssäoppimisen arviointiin, joka tapahtuu tai ainakin nousee todellisista olosuhteista työpaikoilla. Kun oppimista on vaikea arvioida täysin ulkoisesti siksi, että monet opitut asiat esiintyvät hiljaisena tietona, oppijan ajattelumalleissa tai toimintatavoissa, on työssäoppimiseen sovellettava mm. seuraavia menetelmiä: havainnointi, oppimispäiväkirja, näyttökokeet, portfolio sekä 360-asteen arviointi ja palautteen anto, joiden periaatteet ja toteutustavat myös tulevat hyvin esitellyiksi. Artikkeli tuo esille tarpeen kehittää myös arvioinnin muotoja ja välineitä soveltuviksi muuttuviin osaamiskonteksteihin niin, että ne palvelevat myös työyhteisöjen sisäistä kehittämistä.

\section{Kirja antaa lukijalle} runsaasti tarjoumia työssäoppimisen käytännön ymmärtämiseksi. Lukijan on kuitenkin aktiivisesti pyrittävä itse työstämään käsitystä siitä, miten työssäoppimisen kokonaisuus voisi omassa oppilaitoksessa toimia. Systemaattisempi reaalisiin toteutuksiin yhdistäminen olisi voinut luoda teemojen käsittelylle "materiaalisen" pohjan, jolloin olisi vältytty valmiiden mallien tai omiin ajatuksiin pohjautuvilta yleistyksiltä. Koska ilmiselvästi kirjoittajilla on paljon kokemusta työssäoppimisen toteutuksista, olisivat ne voineet selkeämmin toimia materiaalina ja pohdinnan perustana nyt ne toimivat ikään kuin viitteinä ja muun (suuremman) ajattelun todistuksena. Eräät väitteet herättävät tai oletukset herättävät paremmin perustelemattomina monia kysymyksiä. Esimerkiksi kirjan vision mukaan työssäoppiminen on jopa merkittävin uudistus, joka ammatillisessa koulutuksessa on koskaan toteutettu (52), työssäoppiminen on isoissa oppilaitoksissa tiimivetoista (57), erityisesti nopean teknologian kehityksen todetaan olevan oppimisen muutosten taustana (15, 21) tai ohjauksen tavoitteena on vaikuttaminen tai tietoisesti muutoksen aikaansaaminen (127) selittämättä, millaisiin asioihin vaikuttamista ja minkä muutoksen aikaansaamista tarkoitetaan.

\section{Kirja tarjoaa eri}

artikkeleissa myös erilaisia teoreettisia viitekehyksiä.

Toimituksellisella työllä niistä olisi saattanut saada toimivamman kokonaisuuden (esimerkiksi sosialisaatio- tai attribuutioteorioiden laajempi hyväksikäyttäminen tai eri yhteyksissä vilahtavan konstruktiivisen näkökulman tarkentaminen). Kun kirja kuitenkin lähtee praktisesta ilmiöstä ja sen haltuun ottamisesta, johtavat irrallinen teoretisointi ja käytännön yleistykset joissakin kohdin päällekkäisiin tai toisiinsa liittymättömien työssäoppimisen periaatteiden ja hallinnan muotojen käsittelyyn, jolloin lukijan "rekonstruktioprosessi" joutuu koville. Toimituksellinen viimeistely olisi saattanut myös valaista esimerkiksi opiskelijoiden kokemuksia kuvaavien sitaattien alkuperän ja kontekstin, jotka useimmiten jäävät nyt selittämättä samoin kuin monet muutkin mahdollisesti konkreetteihin kokeiluihin tai toteutuksiin liittyvät päätelmät. Lukijana en myöskään löytänyt erään kirjoittajan toista artikkelia, joka tekstin viittauksen mukaan kirjaan piti sisältyä. Joka tapauksessa kirja antaa työssäoppimiseen hyvää pohdittavaa ja erityisesti ohjauksen nostaminen esille jo otsikon tasolla antaa selkeän viitteen sekä opetustyön muuttamisen että vuorovaikutuksen tuottamisessa välttämättömien uusien periaatteiden ja välineiden luomisen tarpeesta.

\section{Kun lainsäädännön henki} on sellainen, että työssäoppimista tulee kehittää yhteistoiminnassa, on itse tuon yhteistoiminnallisen kehittämisen haaste nähtävästi kaikkein suurin. Työssäoppimista ei saada toteutettua pelkästään oppilaitoksen toiminnan tai opetussuunnitelmien muuttamisen näkökulmasta, mitä kirjassa hyvin korostetaan. Tällä hetkellä työssäoppiminen (ja myös työharjoittelu) ja niihin liittyvät uudet järjestelyt ovat kokeilujen asteella siten, että ne nostavat jopa luontaisesti esille eri toimijoita yhdistäviä kehittämiskohteita. Kirjan haasteeksi nousee ideaalien, mallien ja alustavien teoretisointien jälkeen kohota myös sellaiselle analyysitasolle, jossa kuvataan systemaattisesti reaalisia työssäoppimisen käytännön toteutuksista nousevia ristiriitoja ja haasteita. Näiden ristiriitojen tarkka tutkiminen vaikkapa etnometodologinen tunnistaminen ja analyysi saattaisi nostaa esille reaalisia kehittämiskohteita ja motivoida eri toimintajärjestelmien toimijat kaikkia hyödyttäviin, "rajanylityksiä" tuottaviin yhteisiin hankkeisiin.

Heikki Pasanen 